\title{
Screening of Anti-Hyperglycaemic and Anti- Hyperlipidemic Activities of Leaves Extracts of Cassia glauca Lam. on Streptozotocin-Nicotinamide Induced NIDDM Rats
}

\author{
Vinay Kumar Gupta1, Asha Pathak ${ }^{1, *}$, Chandra Veer Singh ${ }^{1}$, Manoj Gahlot², Devender Pathak ${ }^{3}$ \\ 1'Department of Pharmacology, Uttar Pradesh University of Medical Sciences, Saifai, Etawah, Uttar Pradesh, INDIA. \\ ${ }^{2}$ Department of Pharmaceutical Sciences, Shri Guru Ram Rai University, Dehradun, Uttarakhand, INDIA. \\ ${ }^{3}$ College of Pharmacy, Uttar Pradesh University of Medical Sciences, Saifai, Etawah, Uttar Pradesh, INDIA.
}

\begin{abstract}
Aim: The objective of the present study was to screen the anti-hyperglycaemic and antihyperlipidemic activities of leaf extracts (Pet-ether, Chloroform, Acetone, and Methanol) of Cassia glauca Lam. on streptozotocin-nicotinamide induced NIDDM rats. Methods: Acute oral toxicity of all extracts was carried out with a single dose of $2000 \mathrm{mg} / \mathrm{kg}$ in female non-pregnant albino Wistar rats. An oral glucose tolerance test was performed for all extracts in overnight fasted rats. The anti-hyperglycaemic and anti-hyperlipidemic activities were carried out on adult healthy albino Wistar rats of either sex. Diabetogenic drug Streptozotocin and Nicotinamide were administrated by intraperitoneal route. Standard drug glibenclamide was administered by the peroral route. Test drugs (extracts) were administered in doses of $200 \mathrm{mg} / \mathrm{kg}$ by the peroral route. Diabetic rats with serum glucose levels more than $250 \mathrm{mg} / \mathrm{dl}$ were selected for the study. Bodyweight, fasting serum glucose levels, and other biochemical parameters were monitored on the $1^{\text {st }}$, $15^{\text {th }}$, and $21^{\text {st }}$ day. Results: All four-leaf extract showed significant anti-hyperglycemic and lipid-lowering activity. Maximum activity was shown by methanolic extract (effect on $\mathrm{FSGL}=282.20 \pm 5.29$ on day 1 st to $139.20 \pm 3.46$ on $21^{\text {st }}$ day, $p<0.01$ ), (effect on lipid parameters $=\left(T G=105.69 \pm 0.71\right.$ on $15^{\text {th }}$ day to $110.19 \pm 0.70$ on $21^{\text {st }}$ day, $p<0.01, \mathrm{CH}=105.68 \pm 0.50$ on $15^{\text {th }}$ day to $111.37 \pm 0.48$ on $21^{\text {st }}$ day, $p<0.01$ and $\mathrm{S} . \mathrm{HDL}=37.29 \pm 0.22$ on $15^{\text {th }}$ day to $38.05 \pm 0.44$ on $21^{\text {st }}$ day, $p<0.01$. Conclusion: From the present study a conclusion can be drawn that the methanolic extract of $C$. glauca leaves possesses potential anti-hyperglycaemic and anti-hyperlipidemic properties.
\end{abstract}

Key words: Cassia glauca, Streptozotocin, Nicotinamide, Glibenclamide, Serum Glucose Level.

\section{INTRODUCTION}

Diabetes may be defined as a disease where the body either produces less insulin/ceases to produce insulin, or becomes progressively resistant to its action. ${ }^{1}$ A large number of plant preparations have been reported to possess anti-diabetic activity over the last several decades. Researchers in India have documented the use of over 150 plants of various families with hypoglycaemic activity. ${ }^{2,3}$
Cassiaglauca is an ornamental plant belonging to the family Leguminosae (Fabaceae) and subfamily Caesalpinoideae. It is native to Asia India, Thailand, Vietnam, Indonesia, Malaysia, Laos, Ceylon, Polynesia, and the Philippine Islands) and Australia. ${ }^{4}$ The other Synonyms are C. arborescens, $C$. enneaphylla, C. petropolitana, C. sulfurea, C. surattensis subsp. glauca (Lam.), Sennas arborescens and Sennas surattensis. Sennas (from Arabic Sana), is a large genus of flowering
Submission Date: 30-07-2020; Revision Date: 15-12-2020; Accepted Date: 07-06-2021

DOI: 10.5530/ijper.55.4.212 Correspondence: Dr. Asha Pathak Professor, Department of Pharmacology, Uttar Pradesh University of Medical Sciences, Saifai, Etawah-206130, Uttar Pradesh, INDIA. Phone: +91-9451021779 Email id: drasha_pathak@ yahoo.co.in

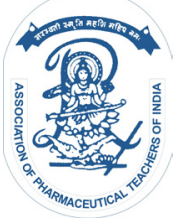

www.ijper.org 
plants. This genus is diverse and native throughout the tropics while a small number of species also reaching into temperate regions. The number of species is estimated at 260. ${ }^{5}$ This genus is distributed all over India, Pakistan, Cylon, Malaysia, China, and South Africa. ${ }^{6}$ Cassia species are well known in folk medicine for their laxative and purgative uses. They are used for antidiabetic and antihyperlipidemic activity and also for treating skin diseases such as ringworm, scabies, eczema, and wounds. ${ }^{7}$ Besides, they have been also found to exhibit anti-inflammatory and hyperglycaemic, ${ }^{8}$ antioxidants, ${ }^{9}$ hypoglycaemic, ${ }^{10}$ antiplasmodial, ${ }^{11}$ larvicidal, ${ }^{12}$ antimutagenic, ${ }^{13}$ and anticancer activities. ${ }^{14}$

Literature survey reveals that $C$. glanca plant possess cytotoxic and hepatoprotective activity in leaves, ${ }^{4}$ anti-hyperglycaemic and anti-hyperlipidemic activity in the bark, ${ }^{15}$ anti-hyperglycaemic activity in leaves ${ }^{16}$ antimicrobial and antioxidant activity in seed, ${ }^{17}$ cytotoxic and antioxidant activity in leaves, ${ }^{18}$ cardioprotective and nephroprotective activity with improved glucose and insulin tolerance. ${ }^{19}$

The present study was conducted for stabilizing the scientific basis of systematic phytochemical investigations of leaf extracts of $C$. glauca followed by screening for anti-hyperglycaemic and anti-hyperlipidemic activities on streptozotocinnicotinamide induced diabetic rats.

\section{MATERIALS AND METHODS}

\section{Collection of Plant Materials}

The leaves of C. glauca were collected from Forest Research Institute, Dehradun, situated at latitude 30020' 31.5312" $\mathrm{N}$ and longitude 7800' 15.156" E, elevation about $2198 \mathrm{ft}$. The specimen collected for authentication was essentially consisted of fruit, seed, flowers, leaves, and stem to readily discernible. The youngest fully developed and mature leaves of the current year's growth were collected and closely examined for insect damage, fungal infections, and mechanical injury. The collected samples were authenticated by The Botanical Survey of India, Dehradun, and accession numbers 114132 was assigned for C. glauca Lam. (Senna sulfurea) family; Caesalpiniaceae. Certificate of authentication vide Ref. no. BSI/NRC/Tech. (Ident.)/2012-13 of dated 06/06/2012 was issued by Dr. H. C. Pande (Scientist-D) of B.S.I. One set of the samples were deposited in the herbarium of Botanical Survey of India, Northern regional center, Dehradun, Uttarakhand, India.

\section{Preparation of Extract}

The extraction was done using soxhlet apparatus. Dried powdered leaves $(2 \mathrm{~kg})$ were extracted successively by a
Soxhlet apparatus with solvents in increasing order of polarity (petroleum ether 40:60, chloroform, acetone, and methanol) ranging from non-polar to polar. Each time before extracting with the next solvent the marc was rinsed and air-dried. All the extracts were concentrated by distilling the solvent at low temperature by a vacuum evaporator. Extracts obtained were weighed and percentages of different extractive values were calculated with respect to air-dried substances. All the extracts were kept in a refrigerator at $2-8^{\circ} \mathrm{C}$ for further use.

\section{Preliminary Phytochemical Screening}

The qualitative chemical tests for various phytoconstituents were carried out as per methods described for all the leaf extracts of C. glauca..$^{20-22}$

\section{Animals}

The present study was carried out on Wistar albino rats of either sex weighing 180-200 gm. Animals were procured from Central Drug Research Institute (CDRI), Lucknow (Uttar Pradesh) and kept in the animal house of The Uttar Pradesh University of Medical Sciences (Formerly UP Rural Institute of Medical Sciences and Research), Saifai, Etawah (CPCSEA registration no. 1087/ac/07/CPCSEA). All rats were transferred and kept, housed in the departmental research laboratory in separate cages under standard laboratory conditions (temperature $25 \pm 2{ }^{\circ} \mathrm{C}$ with a dark and light cycle of 12 hrs) as per the guidelines laid by the Committee for the Purpose of Control and Supervision of Experiments on Animals (CPCSEA).

The animals were kept in the research laboratory to acclimatize to laboratory conditions for a week before the start of the experiment. The rats were fed with a standard pellet diet and water ad-libitum. Food for animals was supplied by CPCSEA approved vendor, $\mathrm{M} / \mathrm{s}$ UP State Agro Industrial Corporation Ltd. Lucknow. Approval from the Institutional Animal Ethics Committee (IAEC) was taken for study (Lt No. 26/AH/RIMS and R/2013-14 dated $13^{\text {th }}$ March, 2012).

\section{Acute Oral Toxicity}

Though it is a normal practice to determine the $\mathrm{LD}_{50}$ value, now it is acceptable to limit the study with an acute toxicity test (Limit Test) without using several doses including reasonably high doses of the drugs. Acute oral toxicity studies of all four leaf extracts of C. glauca were carried out on female non-pregnant albino Wistar rats (150-180 gm). Rats were randomly selected and marked for individual identification. A limit test at a single dose of $2000 \mathrm{mg} / \mathrm{kg}$ was carried out with five groups $(n=3)$. The test substances in a dose of $2000 \mathrm{mg} / \mathrm{kg}$ (ten times more than the therapeutic dose) were administered in a 
single dose volume $(10 \mathrm{ml} / \mathrm{kg})$ the perorally by gavage using an intubation cannula. Rats overnight fasted before dosing. After the administration of extracts, rats were further deprived of food for the next 3-4 hr. ${ }^{23}$

\section{Drug SolutionsPreparation and Dose of Streptozotocin (STZ) Stock Solution}

STZ was procured from Sisco Research Laboratories Pvt. Ltd. (SRL) of batch no. 8685633(98\% assay), mfg. date 06/2014. STZ was available as a dry-frozen, pale yellow, sterilized product. $1 \mathrm{gm}$ of STZ was dissolved in $20 \mathrm{ml}$ of $0.1 \mathrm{M}$ citrate buffer to obtain STZ solution with a $\mathrm{pH}$ of 4.5 and stored at $2-8^{\circ} \mathrm{C}$. STZ stock solution was freshly prepared to induce diabetes in the rat by administrating with a dose of $65 \mathrm{mg} / \mathrm{kg}$ body weight in volume of $1 \mathrm{ml} / \mathrm{kg}$ body weight of rat by intraperitoneal route. The freshly prepared solution of STZ was used for induction of the diabetes in rats.

\section{Preparation of $0.1 \mathrm{M}$ Citrate Buffer}

Citrate buffer $(0.1 \mathrm{M})$ was prepared by mixing citric acid $10.5 \mathrm{gm}$ and sodium citrate $14.7 \mathrm{gm}$ in $500 \mathrm{ml}$ water. The volume was makeup to $2000 \mathrm{ml}$ with distilled water and the $\mathrm{pH}$ was adjusted with 4.5 by sodium hydroxide.

Preparation and Dose of Nicotinamide (NAD) Stock Solution:- Nicotinamide powder was procured from Sigma-Aldrich, product no. N-3376 (98\% assay). NAD was received as a white powder, which became colourless and clear when dissolved to get the solution. $1 \mathrm{gm}$ of NAD was dissolved in $10 \mathrm{ml}$ of $0.9 \%$ $\mathrm{NaCl}$ solution and stored at a cool temperature. The NAD solution was freshly prepared to administer by intraperitoneal route with a dose of $230 \mathrm{mg} / \mathrm{kg}$ body weight in volume of $2.3 \mathrm{ml} / \mathrm{kg}$ body weight of the rat, 15 min before administration of STZ in overnight fasted animals.

Preparation and Dose of Extract Stock Solution:Stock solutions of extracts $(200 \mathrm{mg} / \mathrm{kg}$ body weight of rat) were prepared by dissolving 2 gm of extract in 200 $\mathrm{ml}$ of the vehicle (2\% Tween-80). The stock solution of extract was administered with a volume of $10 \mathrm{ml} / \mathrm{kg}$ body weight of rat by the peroral route.

Preparation and Dose of Standard Drug (Glibenclamide) Stock Solution:- Glibenclamide (USV Ltd. Baddi, Solan, HP) stock solution was prepared by dissolving $50 \mathrm{mg}$ of the drug in $200 \mathrm{ml}$ of the vehicle $(2 \%$ Tween-80). The standard drug in the form of stock solution $(5 \mathrm{mg} / \mathrm{kg})$ was administered with a volume of $10 \mathrm{ml} / \mathrm{kg}$ body weight of rat by the peroral route.

Procedure for Estimation of Serum Glucose (GOD-POD Method):- Blood samples were collected in fluoride vials from retro-orbital plexus of rats for estimation of serum glucose level. Blood was left to coagulate; centrifuged and clear non-hemolyzed serum was obtained for determination of glucose concentration. Separated plasma samples were stored at $4-8^{\circ} \mathrm{C}$ for further estimation of glucose. The FSGL was measured by the glucose oxidase-peroxide method (GOD-POD).

Induction of Non-Insulin Dependent Diabetes Mellitus (NIDDM) by STZ-NAD:- In overnight fasted albino Wistar rats of either sex, NIDDM was induced by intraperitoneal injections of STZ $65 \mathrm{mg} / \mathrm{kg}$ body weight and NAD $230 \mathrm{mg} / \mathrm{kg}$ body weight. NAD was administered 15 min before administration of STZ. After induction of diabetes, fasting serum glucose levels of animals were randomly monitored for two weeks. After two weeks of induction of diabetes, rats with a fasting serum glucose level of more than $250 \mathrm{mg} / \mathrm{dl}$ were selected for the study. Study (Treatment) of extracts on animals was started on the $15^{\text {th }}$ day after administration of STZ-NAD. ${ }^{24}$

Oral Glucose Tolerance Test (OGTT):- OGTT was performed for all extracts in overnight fasted rats. Rats were divided into five groups of six animals in each group $(n=6)$. Group, I served as normal control and received only vehicle $(2 \%$ Tween- 80$)$ by the peroral route. Groups II-V received stock solutions of pet-ether, chloroform, acetone, and methanol extract of C. glauca by the peroral route. After 30 min of extract administration, the rats of all groups were loaded with glucose in a dose of $2.0 \mathrm{gm} /$ $\mathrm{kg}$ body weight the perorally. The rats were restrained in rat restrainers and blood was withdrawn from the tail vein by making a small incision just prior to the glucose administration ( $0 \mathrm{~min}$ ) and at intervals of 30, 60, $120 \mathrm{~min}$ after loading of glucose. Blood glucose level (BGL) was measured by using a glucose test strip and a glucometer (Accu-Chek - Active, Roche Diabetes Care, Germany).

Experimental Design for Anti-Hyperglycaemic (Anti-diabetic) Activity:- Adult healthy albino Wistar rats of either sex were taken for study. Diabetogenic drug STZ and NAD solutions were administered for induction of diabetes in experimental rats. The NAD was administered $15 \mathrm{~min}$ before administration of STZ. After induction of diabetes, fasting serum glucose levels (FSGL) of animals were randomly monitored for two weeks and after two weeks the rats with FSGL of more than $250 \mathrm{mg} / \mathrm{dl}$ were selected for the study. Rats were allowed to drink 5\% glucose solution overnight to overcome drug-induced hypoglycemia. Normal control rats were injected with citrate buffer as a placebo.

Study (Treatment) of extracts on animals was started on the $15^{\text {th }}$ day after administration of STZ-NAD and this $15^{\text {th }}$ day was considered as day $1^{\text {st }}$ of study. Treatment 
was subsequently continued for further 21 days with once-daily dosing by the peroral gavage of the vehicle to normal control rats (Group-I) and diabetic control rats (Group-II), a stock solution of a standard drug (glibenclamide) to diabetic rats (Group-III), and stock solutions of test drugs (extracts) to diabetic rats with pet-ether, chloroform, acetone, methanol extracts of C. glanca to groups IV to VII respectively. Bodyweight, FSGL, and other biochemical parameters were monitored on day $1^{\text {st }}$, day, $15^{\text {th }}$ and day $21^{\text {st }}$.

Rats have fasted overnight and blood was taken under mild anaesthesia of ether from retro-orbital plexus in fluoride vial for estimation of serum glucose and a plain vial for estimation of other biochemical parameters. Serum was separated by centrifugation at $4000 \mathrm{rpm}$ for $15 \mathrm{~min}$ and FSGL was measured. The separated serum of plain vial was further used for estimation of triglycerides, total cholesterol, and HDL.

Procedure for Estimation of Serum Total Cholesterol:- For estimation of total cholesterol, the cholesterol oxidase peroxidase method (CHOD-POD) was used with the Span cogent diagnostics kit.

Procedure for Estimation of Serum Triglycerides:For estimation of triglycerides, endpoint colorimetry, enzymatic test using glycerol-3- phosphate oxidase method was used with the Span diagnostic kit.

Procedure for Estimation of High-Density Lipoprotein Cholesterol (HDL):- For estimation of HDL cholesterol, the CHOD-POD method was used with the Span cogent diagnostic kit.

Animal Bodyweight:- The individual bodyweight of all treatment groups was observed as initial and at the end of the study. The mean change in bodyweight of rats was calculated and tabulated.

Statistical Analysis:- Data were expressed as the mean \pm S.E.M. The significance of the results was calculated using one way ANOVA followed by the Dunnett t-test by applying software SPSS, version 21, and the results were considered statistically significant (when $p<0.05$ ).

\section{RESULTS}

Phytochemical Testing:- The results of the qualitative phytochemical analysis showed the presence of flavonoids, phenolic compounds, tannins, alkaloids, glycosides, and carbohydrates in a good entity in methanolic extracts of C. glauca.

Acute Oral Toxicity Studies (OECD - 423):- In the present study, acute oral toxicity was tested with a dose of $2000 \mathrm{mg} / \mathrm{kg}$ and found that at this dose the extracts did not exhibit any sign of toxicity. Rats were observed individually after dosing during the first 30 min critically followed by, periodically during the first $24 \mathrm{hr}$, with special attention given during the first $4 \mathrm{hr}$. It was found that there were no clinical signs, and significant changes noticed in the skin and fur, eyes, and mucous membranes, respiratory rate, circulatory signs, ANS (salivation, perspiration, urinary, and defecation), and CNS (drowsiness, gait, tremors, and convulsion) along with body weight, and behaviour pattern.

The animals were observed for a further 14 days for any sign of delayed toxicity or impending death. The extracts of $C$. glauca did not show any lethal effect on the animals for a testing dose of $2000 \mathrm{mg} / \mathrm{kg}$. Therefore, it was presumed that the $\mathrm{LD}_{50}$ value is expected to be higher than $2000 \mathrm{mg} / \mathrm{kg}$, and based on this the $\mathrm{ED}_{50}$ $\left(1 / 10^{\text {th }}\right.$ of $\left.\mathrm{LD}_{50}\right)$ of test substances was taken as 200 $\mathrm{mg} / \mathrm{kg}$.

Oral Glucose Tolerance Test for C. glauca: The effect of all extracts of $C$. glauca along with the vehicle control group on OGTT is summarized in Table 1. BGL was found in close range among all groups when blood was withdrawn just before the glucose administration (0 min). Maximum BGL was found when blood was withdrawn after $30 \mathrm{~min}$ of glucose administration in all groups. The vehicle control group had a significant elevation in BGL in the entire measurement period in comparison with extract-treated groups.

Among all extract-treated groups, BGL significantly $(\phi<0.01)$ resettled close to the initial normal level (i.e., 0 min) when blood was withdrawn by 120 min of glucose administration. Maximum decline in BGL at intervals of 30 and 60 min was observed significantly $(p<0.01)$ in the methanolic extract group in comparison to the vehicle control group and other extract groups. In comparison to the vehicle control group, the highest BGL values were found in the chloroform extract group.

The OGTT study revealed that all extracts of C. glauca were lowering BGL in comparison with the vehicle control group, after loading of glucose by the peroral route and among all tested extracts; the methanolic group was founded more effective. Therefore, extracts of C. glanca are considered relevant for the evaluation of anti-diabetic study in rats.

\section{Effect of C. glauca Leaf Extracts on FSGL in STZ- NAD Induced NIDDM Diabetic Rats}

Results observed for FSGL (mg/dl) in experimental rats in a normal control group, diabetic control group, the diabetic group treated with standard drug glibenclamide, and other diabetic groups treated with leaves extracts of C. glauca with a dose of $200 \mathrm{mg} / \mathrm{kg}$ is summarized in Table 2. The values of FSGL obtained by standard drug and test extracts were compared with the diabetic 
control group by applying one way ANOVA followed by Dunnett t-test. The values were presented as mean \pm S.E.M. and the result was considered statistically significant when $p<0.05$.

The FSGL was in close range among the normal control group $(84.00 \pm 1.14$ on the first day to $82.80 \pm .58$ on the $21^{\text {st }}$ day). In the diabetic control group, there was a significant elevation in FSGL throughout the study period $\left(272.00 \pm 6.47\right.$ on the $1^{\text {st }}$ day to $300.80 \pm 5.75$ on the $21^{\text {st }}$ day. $\left.p<0.01\right)$. In all the extract-treated groups, FSGL was very significantly declined when compared with the diabetic control group. In Pet ether extract group, there was a decline in FSGL from $287.80 \pm$ 2.90 on the $1^{\text {st }}$ day to $218.20 \pm 3.29$ on the $21^{\text {st }}$ day, $p$ 0.01 . In the chloroform extract-treated group, there was decline in FSGL from $279 \pm 5.25$ on the $1^{\text {st }}$ day to $216.00 \pm 6.01$ on the $21^{\text {st }}$ day, $p<0.01$.

There was a decline in FSGL from $278.80 \pm 6.18$ on day $1^{\text {st }}$ to $186.20 \pm 5.69$ on day $21^{\text {st }} p<0.01$ and $282.20 \pm 5.29$ on day $1^{\text {st }}$ to $139.20 \pm 3.46$ on $21^{\text {st }}$ day, $p<0.01$, in acetone extract-treated group and methanol extract-treated group respectively. A maximum percentage decline in FSGL value was observed in the Glibenclaimide treated group $(62.55 \%)$. Among extract-treated groups, the maximum reduction in FSGL was found in the methanol extract-treated group (50.67\%).

Anti-Hyperlipidemic Activity of C. glauca Leaves Extracts:- During the study, the treatment for all groups was continued for 21 days with once-daily administration of vehicle, stock solutions of standard drug glibenclamide, and stock solution of various extracts of $C$. glauca to rats of the respective groups by the peroral gavage route. Biochemical parameters related to lipid profile like Serum Triglycerides (TG), Serum Total Cholesterol (TC), and Serum high-density lipoproteins (HDL) were monitored on day $1^{\text {st }}$, day $15^{\text {th }}$ and day $21^{\text {st }}$.

The effect of leaves extract on various lipid parameters are following: In the diabetic control group, there was a significant increase in TG $\left(159.49 \pm 1.00\right.$ on $1^{\text {st }}$ day to $170.71 \pm 0.79$ on $21^{\text {st }}$ day, $\left.p<0.01\right)$ and cholesterol values $\left(131.01 \pm 1.19\right.$ on day $15^{\text {th }}$ to $152.52 \pm 0.99$ on day $21^{\text {st }}$, $p<0.01)$ and decline in HDL values $(30.62 \pm 0.48$ on day $15^{\text {th }}$ to $29.26 \pm 0.34$ on $21^{\text {st }}$ day, $\left.p<0.01\right)$. The effect of Glibenclaimide on various lipid parameters was very significant as compared to the diabetic control group

\begin{tabular}{|c|c|c|c|c|}
\hline \multicolumn{5}{|c|}{ Table 1: Effect of C. glauca leaves extracts on Blood Glucose Level of rats. } \\
\hline Groups & $\mathbf{0 ~ M i n ~}$ & $\mathbf{3 0}$ Min & $\mathbf{6 0}$ Min & $\mathbf{1 2 0}$ Min \\
\hline Vehicle Control & $81.50 \pm 0.76$ & $150.83 \pm 0.79$ & $121.33 \pm 0.88$ & $100.50 \pm 0.92$ \\
\hline $\begin{array}{c}\text { Pet-Ether Extract } \\
(40: 60)\end{array}$ & $83.67 \pm 0.49$ & $120.50 \pm 0.76^{* *}$ & $104.50 \pm 0.76^{* *}$ & $84.83 \pm 0.60^{* *}$ \\
\hline Chloroform Extract & $81.50 \pm 0.85$ & $126.17 \pm 0.94^{* *}$ & $110.17 \pm 1.05^{* *}$ & $85.17 \pm 0.54^{* *}$ \\
\hline Acetone Extract & $84.33 \pm 0.42$ & $118.17 \pm 1.05^{* *}$ & $94.33 \pm 0.84^{* *}$ & $83.17 \pm 0.95^{* *}$ \\
\hline Methanol Extract & $83.83 \pm 0.31$ & $110.83 \pm 0.60^{* *}$ & $90.67 \pm 0.56^{* *}$ & $82.17 \pm 0.98^{\star *}$ \\
\hline
\end{tabular}

Values are presented as Mean \pm SEM $(n=6)$. One way ANOVA followed by Dunnett t-test was applied and the mean difference was found statistically significant at 0.05 level $(* * p<0.01)$ when compared with the vehicle control group.

Table 2: Effect of standard drug and various extracts $(200 \mathrm{mg} / \mathrm{kg})$ of C. glauca on FSGL ( $\mathrm{mg} / \mathrm{dl})$ in STZ-NAD induced NIDDM rats. Study (Treatment) of extracts on animals was started on the $15^{\text {th }}$ day after administration of STZ-NAD and this $15^{\text {th }}$ day was considered as day $1^{\text {st }}$ of study.

\begin{tabular}{|c|c|c|c|}
\hline \multirow[t]{2}{*}{ Groups with Treatment } & \multicolumn{3}{|c|}{ FSGL (mg/dl) } \\
\hline & $1^{\text {st }}$ Day & $15^{\text {th }}$ Day & $21^{\text {st }}$ Day \\
\hline Normal Control & $84.00 \pm 1.14$ & $83.20 \pm .66$ & $82.80 \pm 0.58$ \\
\hline Diabetic Control & $272.00 \pm 6.47^{\# \#}$ & $281.80 \pm 6.06^{\# \#}$ & $300.80 \pm 5.75^{\# \#}$ \\
\hline Glibenclamide & $275.60 \pm 7.55$ & $165.40 \pm 8.09^{* *}$ & $103.2 \pm 3.26^{* *}$ \\
\hline Pet-Ether Extract (40:60) & $287.80 \pm 2.90$ & $247.40 \pm 2.87^{* *}$ & $218.20 \pm 3.29^{* *}$ \\
\hline Chloroform Extract & $279.40 \pm 5.25$ & $238.60 \pm 9.65^{\star *}$ & $216.00 \pm 6.01^{* *}$ \\
\hline Acetone Extract & $278.80 \pm 6.18$ & $220.60 \pm 4.49^{* *}$ & $186.20 \pm 5.69^{* *}$ \\
\hline Methanol Extract & $282.20 \pm 5.29$ & $213.60 \pm 3.52^{* *}$ & $139.20 \pm 3.46^{* *}$ \\
\hline
\end{tabular}

Values are presented as Mean \pm SEM ( $n=5)$. One way ANOVA followed by Dunnett t- test was applied. The mean difference was found statistically significant at 0.05 level $(* * p<0.01)$ when all the groups were compared with the diabetic control group and $(\# \# p<0.01)$ when the diabetic control compared with normal control. 
and other extract-treated groups. (S. Triglycerides= $110.99 \pm 1.39$ on $15^{\text {th }}$ day to $106.92 \pm 0.97$ on $21^{\text {st }}$ day, S. Total Cholesterol $=101.76 \pm 1.26$ on $15^{\text {th }}$ day and $108.79 \pm 0.74$ on $21^{\text {st }}$ day and S. HDL $40.28 \pm 0.66$ on $15^{\text {th }}$ day to $40.56 \pm 0.50$ on $21^{\text {st }}$ day, $p<0.01$.

Among extract-treated groups, improvements in various parameters of lipid profile were seen in all extracttreated groups but the maximum reduction in TG and $\mathrm{CH}$, and increment in S.HDL was seen in Methanolic extract-treated group (TG $=105.69 \pm 0.71$ on $15^{\text {th }}$ day to $110.19 \pm 0.70$ on $21^{\text {st }}$ day, $p<0.01, \mathrm{CH}=105.68 \pm 0.50$ on $15^{\text {th }}$ day to $111.37 \pm 0.48$ on $21^{\text {st }}$ day, $p<0.01$ and S.HDL $=$ $37.29 \pm 0.22$ on $15^{\text {th }}$ day to $38.05 \pm 0.44$ on $21^{\text {st }}$ day, $p<0.01$. The observed values were noted and summarized in Table 3. The result showed that an increase in hyperglycemia also affects biochemical parameters in rats.

Effect of C. glauca Leaves Extracts on Change in Bodyweight of Rats:- Bodyweight of animals of all groups was monitored from time to time in the study. The effect of all extracts of C.glauca along with the group treated with standard drug and control groups on body weight of rats was recorded on $1^{\text {st }}$ day at the initiation of the study and also at the last day $\left(21^{\text {st }}\right.$ day). The observed values are summarized in Table 4. Significant increase in body weight was observed on the $21^{\text {st }}$ day in animals of the control group $\left(189.80 \pm 2.96\right.$ on $1^{\text {st }}$ day to $210.60 \pm 3.75$ on $21^{\text {st }}$ day) while a decrease in body weight was found in animals of the diabetic control group (191.20 \pm 3.26 on 1 st day to $183.80 \pm 3.56$ on $21^{\text {st }}$ day, $\left.p<0.01\right)$. Among extract-treated groups, a significant increase in body weight was found on the $21^{\text {st }}$ day when compared with the diabetic control group. The maximum increase was found in the acetone extract-treated group $(188.80 \pm 2.75$ on the $1^{\text {st }}$ day to $207.60 \pm 2.03$ on the $21^{\text {st }}$ day, $p<0.01$. The bodyweight of the group treated with standard drug also increased significantly on the $21^{\text {st }}$ day $(192.20 \pm 2.69$ on the $1^{\text {st }}$ day to $208.80 \pm 2.78$ on the $21^{\text {st }}$ day, $\left.p<0.01\right)$.

\section{DISCUSSION}

The present study aimed to screen the antihyperglycaemic and anti-hyperlipidemic activities of leaf extracts of $C$. glauca in STZ-NAD induced NIDDM rats. During the study, the hyperglycaemia produced by STZ-NAD model manifested mild hyperglycemia. Treatment of pre-diabetic with NAD improves diabetic metabolic alterations, most likely by counteracting betacell dysfunction and loss associated with oxidative stress. Treatment with NAD provides protection against free radicals and oxidative stress improves neurological outcomes and reduces infarct volume in transient and ischemia in vivo. ${ }^{25}$ Rats treated with STZ and NAD manifest symptoms of relatively mild diabetes compared with animals induced by STZ alone. Importantly, $\beta$-cells in these rats were partially damaged, and therefore insulin secretion in response to glucose and some other stimuli is preserved. Moreover, STZ is well known to cause damage to pancreatic $\beta$-cells, whereas NAD partially protects these cells against the detrimental effects of STZ. 26,27

In the present research, results of the qualitative phytochemical analysis showed the presence of flavonoids, phenolic compounds, tannins, alkaloids, glycosides, and carbohydrates in a good entity in all extracts, especially the presence of flavonoids in methanolic extract. In acute oral toxicity, no clinical signs or any significant changes noticed in the skin, fur, eyes, mucous membranes, respiratory rate, circulatory signs, ANS (salivation, perspiration, urinary and defecation) and CNS (drowsiness, gait, tremors and convulsion) along with body weight and behaviour pattern of rats. Therefore, it revealed that the test drug is potentially safe and did not carry any toxicity even at ten times more dose than the therapeutic dose.

The OGTT study showed that all extracts of $C$. glauca leaves were lowering the blood glucose levels in comparison with vehicle control groups. Further, it was observed that the methanolic extract of $C$. glauca leaves was found more significant in lowering blood glucose level. Thus the leaf extracts of C. glauca were considered relevant for the screening of anti-hyperglycaemic activity in rats.

On screening of anti-hyperglycaemic activity, FSGL was found almost nearby in all rats of normal control nondiabetic group fed only with the vehicle as placebo while the diabetic control group showed significant elevation in FSGL throughout the study period which revealed that depriving of anti-diabetic agent leads to continuous elevation in blood sugar among diabetic rats. The decrease in FSGL in all extract-treated groups was found significant $(p<0.01)$ when compared with the diabetic control group. Maximum FSGL reduction (62.55\%) was observed in the group treated with the standard drug (glibenclamide) while among extract-treated group, the maximum reduction was observed in the group treated with methanol extract $(50.67 \%)$ followed by acetone extract $(33.21 \%)$, pet-ether extract $(24.18 \%)$ and least with chloroform extract $(22.67 \%)$. Screening of antihyperglycaemic activity showed that the methanolic extract possesses potential serum glucose-lowering property.

The results of anti-hyperlipidemic activity showed that all the biochemical parameters were almost nearby in the normal control non-diabetic group treated only with the 
Table 3: Effect of various extracts $(200 \mathrm{mg} / \mathrm{kg})$ of C. glauca leaves on Serum Triglyceride $(\mathrm{mg} / \mathrm{dl})$, Serum Total Cholesterol (mg/dl) and HDL (mg/dl) levels in STZ-NAD induced NIDDM rats. Study (Treatment) of extracts on animals was started on the $15^{\text {th }}$ day after administration of STZ-NAD and this $15^{\text {th }}$ day was considered as day $1^{\text {st }}$ of study.

\begin{tabular}{|c|c|c|c|c|}
\hline Groups with Treatment & Days & $\begin{array}{l}\text { Serum Triglycerides (mg/ } \\
\text { dl) }\end{array}$ & $\begin{array}{c}\text { Serum Total Cholesterol } \\
(\mathrm{mg} / \mathrm{dl})\end{array}$ & $\begin{array}{l}\text { Serum HDL (mg } \\
\text { dl) }\end{array}$ \\
\hline \multirow{3}{*}{ Normal Control } & $1^{\text {st }}$ & $81.36 \pm 1.08$ & $70.03 \pm 0.84$ & $44.63 \pm 1.15$ \\
\hline & $15^{\text {th }}$ & $84.67 \pm 0.63$ & $72.20 \pm 0.76$ & $44.94 \pm 0.85$ \\
\hline & $21^{\text {st }}$ & $82.13 \pm 0.88$ & $70.50 \pm 0.51$ & $44.65 \pm 1.25$ \\
\hline \multirow{3}{*}{ Diabetic Control } & $1^{\text {st }}$ & $94.02 \pm 1.07$ & $84.78 \pm 0.41$ & $35.47 \pm 1.01$ \\
\hline & $15^{\text {th }}$ & $159.49 \pm 1.00^{\#}$ & $131.01 \pm 1.19^{\# \#}$ & $30.62 \pm 0.48^{\# \#}$ \\
\hline & $21^{\text {st }}$ & $170.71 \pm 0.79 \#$ & $152.52 \pm 0.99^{\# \#}$ & $29.26 \pm 0.34^{\# \#}$ \\
\hline \multirow{3}{*}{ Glibenclamide } & $1^{\text {st }}$ & $87.95 \pm 0.68$ & $75.44 \pm 0.76$ & $42.19 \pm 0.71$ \\
\hline & $15^{\text {th }}$ & $110.99 \pm 1.39^{* *}$ & $101.76 \pm 1.26^{* *}$ & $40.28 \pm 0.66^{\star *}$ \\
\hline & $21^{\text {st }}$ & $106.92 \pm 0.97^{\star *}$ & $108.79 \pm 0.74^{* *}$ & $40.56 \pm 0.50^{\star *}$ \\
\hline \multirow{3}{*}{ Pet-Ether Extract (40:60) } & $1^{\text {st }}$ & $92.49 \pm 0.62$ & $81.09 \pm 0.41$ & $37.12 \pm 0.59$ \\
\hline & $15^{\text {th }}$ & $115.27 \pm 0.41^{\star *}$ & $109.19 \pm 1.01^{* *}$ & $33.42 \pm 0.33^{* *}$ \\
\hline & $21^{\text {st }}$ & $120.56 \pm 1.61^{* *}$ & $114.89 \pm 0.36^{* *}$ & $31.91 \pm 0.40^{* *}$ \\
\hline \multirow{3}{*}{ Chloroform Extract } & $1^{\text {st }}$ & $92.67 \pm 0.64$ & $81.54 \pm 0.35$ & $37.42 \pm 0.49$ \\
\hline & $15^{\text {th }}$ & $114.97 \pm 0.61^{* *}$ & $112.64 \pm 0.62^{* *}$ & $32.06 \pm 0.40^{* *}$ \\
\hline & $21^{\text {st }}$ & $122.39 \pm 2.17^{* *}$ & $117.51 \pm 0.50^{* *}$ & $30.27 \pm 0.41^{\star *}$ \\
\hline \multirow{3}{*}{ Acetone Extract } & $1^{\text {st }}$ & $92.13 \pm 0.46$ & $79.38 \pm 0.35$ & $38.25 \pm 0.18$ \\
\hline & $15^{\text {th }}$ & $112.19 \pm 0.41^{* *}$ & $108.79 \pm 0.61^{* *}$ & $35.79 \pm 0.54^{\star *}$ \\
\hline & $21^{\text {st }}$ & $116.51 \pm 0.46^{* *}$ & $115.08 \pm 0.66^{\star *}$ & $35.12 \pm 0.67^{* *}$ \\
\hline \multirow{3}{*}{ Methanol Extract } & $1^{\text {st }}$ & $90.16 \pm 0.38$ & $77.79 \pm 0.41$ & $40.11 \pm 0.54$ \\
\hline & $15^{\text {th }}$ & $105.69 \pm 0.71^{\star *}$ & $105.68 \pm 0.50^{* *}$ & $37.29 \pm 0.22^{* *}$ \\
\hline & $21^{\text {st }}$ & $110.19 \pm 0.70^{* *}$ & $111.37 \pm 0.48^{* *}$ & $38.05 \pm 0.44^{\star *}$ \\
\hline
\end{tabular}

Values are presented as Mean \pm SEM $(n=5)$. One way ANOVA followed by Dunnett t-test was applied. The mean difference was found statistically significant at 0.05 level $(* * p<0.01)$ when all the groups were compared with the diabetic control group, and $(\# \# p<0.01)$ when the diabetic control compared with normalcontrol.

vehicle as a placebo, while the diabetic control group showed a significant increase in TG and TC and decrease in HDL value during the study period. Hyperglycaemia produced by STZ-NAD exhibited a marked increase in serum triglycerides and total cholesterol. The tested biochemical parameters (TG, TC and HDL) of glibenclamide treated group showed maximum and significant $(p<0.01)$ improvements in comparison to diabetic control group as well as also with other treated extracts on day $21^{\text {st }}$. Among all extract-treated groups, maximum significant $(p<0.01)$ improvement for testing parameters were observed with the methanolic extract of $C$. glauca. Thus the result showed that an increase in hyperglycemia also altered biochemical parameters in rats.

Bodyweight of animals of all groups was also monitored from time to time in the study. The results showed that there was a significant increase in body weight at the end of the experiment in the normal control group while the characteristic loss was observed in the diabetic

\begin{tabular}{|c|c|c|}
\hline \multirow[t]{2}{*}{ Groups with Treatment } & \multicolumn{2}{|c|}{ Change in Body Weight } \\
\hline & $1^{\text {st }}$ Day & $21^{\text {st }}$ Day \\
\hline Normal Control & $189.80 \pm 2.96$ & $210.60 \pm 3.75$ \\
\hline Diabetic Control & $191.20 \pm 3.26$ & $183.80 \pm 3.56^{\# \#}$ \\
\hline Glibenclamide & $192.20 \pm 2.69$ & $208.80 \pm 2.78^{* *}$ \\
\hline Pet-Ether Extract (40:60) & $190.00 \pm 2.98$ & $201.60 \pm 2.56^{\star *}$ \\
\hline Chloroform Extract & $191.60 \pm 3.39$ & $206.40 \pm 2.90^{* *}$ \\
\hline Acetone Extract & $188.80 \pm 2.75$ & $207.60 \pm 2.03^{\star *}$ \\
\hline Methanol Extract & $188.40 \pm 2.48$ & $202.20 \pm 2.96^{\star \star}$ \\
\hline
\end{tabular}

Values are presented as Mean \pm SEM $(n=5)$. One way ANOVA followed by Dunnett $\mathrm{t}$-test was applied. The mean difference was found statistically significant at 0.05 level $(* * p<0.01)$ when all the groups were compared with the diabetic control group and $(\# p<0.01)$ when diabetic control compared with normal control.

control group. The remarkable loss of body weight in the diabetic control group was expected due to an 
increase in wasting of muscles and also because of loss of tissue proteins. ${ }^{28}$ The body weight of rats was significantly increased $(p<0.01)$ in the group treated with the standard drug as well as in extract-treated groups which maybe because of the property of these drugs in terms of protecting the wasting of muscles (reversal of gluconeogenesis) and also because of adequate control of serum glucose. Thus the change in body weight indicates that hyperglycemia may be one of the factors for the decrease of body weight in rats of the diabetic control group.The findings of phytochemical and screening studies revealed that among all tested extracts of C. glauca, the most potential is a methanolic extract in terms of possessing the highest anti-hyperglycaemic and lipid-lowering properties. Thus the methanolic extract may be considered to have a good anti-hyperglycaemic activity which did not cause any hypoglycemic effect throughout the study period unlike insulin and other available synthetic drugs. Reduction of serum glucose level by the methanolic extract was close to the standard drug which also explains about a normalization of biochemical parameters in terms of lowering of serum triglycerides and serum cholesterol while maintenance of serum HDL, in comparison of the diabetic control group.

Flavonoids, a group of phenolic derivatives with diverse chemical structures, are widely distributed in plants. Flavonoids possess a variety of biological activities viz., anti-inflammatory, anti-fertility, anti-neoplastic, hepatoprotective, anti-ulcer, antioxidant, cardiotonic, anti-microbial, anti-viral, anti-diabetic and gained much interest as bioactive constituents. Flavonoids are wellknown phytoconstituents with anti-diabetic potential. In a study with rutin, a flavonol glycoside in diabetic mice showed significant lowering of plasma glucose level along with an increase in insulin levels and also found the restoration of glycogen content and the activities of carbohydrate metabolic enzymes. ${ }^{29}$ Another flavonoid, luteolin was also found in improving the insulin secretion in uric acid damaged pancreatic $\beta$-cells by suppressing the decrease of MafA mainly through the $\mathrm{NF}-x \mathrm{~B}$, iNOS-NO signaling pathway. ${ }^{30}$ Several studies have reported the mechanism of action of quercetin, a flavonol in diabetes in terms of decreasing lipid peroxidation, increase in antioxidant enzymes along with inhibition of insulin-dependent activation of $\mathrm{PI}_{3} \mathrm{~K}$, and reduction in intestinal glucose absorption by inhibiting GLUT $_{2}{ }^{31,32}$

Based on these results, the hypothesis of control of hyperglycemia in groups treated with extract of $C$. glauca may be due to the presence of flavonoids and other important phytoconstituents which were probably responsible for the mechanism of action by stimulation of insulin secretion from pancreatic $\beta$-cells of islets ${ }^{33}$ and also due to prevention of oxidative stress which is possibly involved in pancreatic $\beta$-cells dysfunction in diabetes may be proposed. ${ }^{34}$

\section{CONCLUSION}

The results of the present study revealed that the methanolic extract of C. glauca leaves possesses potential anti-hyperglycaemic and anti-hyperlipidemic properties. The findings of the study pave the pathway for researchers to correlate important phytoconstituents of these plant extracts in terms of their pharmacological effects. In the future, depending on the principles of the present research, further pharmacological evaluation of isolated compounds is required in an attempt of developing a new anti-hyperglycaemic drug.

\section{ACKNOWLEDGEMENT}

The authors are thankful to all faculties and staff of the Department of Pharmacology, veterinary officer and administration of the Uttar Pradesh University of Medical Sciences, Saifai, Etawah, Uttar Pradesh, India, and also to the management of SGRRIST, Patel Nagar, Dehradun, Uttarakhand, India for providing necessary support and facilities.

\section{CONFLICT OF INTEREST}

The authors declare no conflict of interest.

\section{ABBREVIATIONS}

NIDDM: Non-Insulin Dependent Diabetes Mellitus; Pet-ether: Petroleum Ether; STZ: Streptozotocin; NAD: Nicotinamide; HDL: High Density Lipoprotein; TG: Serum Triglycerides; TC: Serum Total Cholesterol; CDRI: Central Drug Research Institute; CPCSEA: Committee for the Purpose of Control and Supervision of Experiments on Animals; IAEC: Institutional Animal Ethics Committee; LD: Lethal Dose; M: Molar; GODPOD: Glucose oxidase-peroxide method; BGL: Blood Glucose Level; FSGL: Fasting Serum Glucose Level; CHOD-POD: Cholesterol oxidase peroxidase method; SEM: Standard Error of Mean; ANOVA: Analysis of variance; SPSS: Statistical Package for Social Science; OECD: Organization for Economic Co-operation and Development; ANS: Autonomic Nervous System; CNS: Central Nervous System; OGTT: Oral Glucose Tolerance Test. 


\section{REFERENCES}

1. Ranjan C, Ramanujam R. Diabetes and insulin resistance associated disorders: Diseases and the therapy. Curr Sci. 2002;83:1533-8.

2. Patel PM, Patel KN, Patel NM, Goyal RK. Development of HPTLC method for estimation of charantin in herbal formulations. Pharmacog Mag. 2006;2(8):224-6.

3. Sonawane HB, Ghole VS, Garad S, Bapat G, Bhosle S, Apte K. Hypoglycemic Effect of Phansomba (Phellinus badius Berk Ex Cooke) G. Cunn. On Alloxaninduced diabetic rats. Journal of Natural Remedies. 2013;13(1):29-4.

4. El-Sawi SA, Sleem AA. Flavonoids and hepatoprotective activity of leaves of Seena surattensis (Burm.f.) In $\mathrm{CCl}_{4}$ induced hepatotoxicity in rats. Australian $\mathrm{J}$ of Basic and Applied Sciences. 2010;4(6):1326-34.

5. Brigitte $M$, Endress $P K$, DeLuciano $P Q$, Elena C. Phylogenetic relationship within Seena (Leguminosae, Cassiinae) based on three chloroplast DNA regions: Patterns in the evolution of floral symmetry and extra floral nectarines. American Journal of Botany. 2006;03(2):288-303.

6. Chopra RN, Nayar SL, Chopra IC. Glossary of Indian Medicinal Plants. $1^{\text {st }}$ ed. CSIR: New Delhi, India. 1956;54.

7. Gupta VK, Pathak A, Gahlot M, Verma RC, Singh CV. Impact of vitamins in prevention of risk factors associated with type-2 diabetes mellitus. International Journal of Pharmaceutical Sciences and Research. 2013;4(4):1335-47.

8. Somchit MN, Reezal I, Nur IE, Mutalib AR. In vitro antimicrobial activity of ethanol and water extracts of Cassia alata. J. Ethanopharmacol. 2003;84(1):14.

9. Yen GC, Duh PD, Chuang DY. Antioxidant activity of anthraquinones and antraone. Food Chem. 2000;70(4):437-41.

10. Jalalpure SS, Patil MB, Aruna P, Shah BN, Salahuddin MD. Antidiabetic activity of Cassia auriculata seeds in alloxan induced diabetic rats. Niger $\mathrm{J}$ Nat Prod Med. 2004;8:22-3.

11. Iwalewa EO, Lege-Oguntoye L, Rai PP, lyaniwura TT. In vivo and in vitro antimalarial activity of two crude extracts of Cassia occidentalis leaf. Nig J Pharm Sci. 1997;5:23-8.

12. Yang Y, Lim M, Lee H. Emodin isolated from Cassia obtusifolia (Leguminosae) seed shows larvicidal activity against three mosquito species. J Agric Food Chem. 2003;51(26):7629-31.

13. Silva CR, Monteiro MR, Rocha HM, Ribeiro AF, Caldeira-de-Araujo A, Leitao $\mathrm{AC}$, et al. Assessment of antimutagenic and genotoxic potential of senna (Cassia angustifolia Vahl) aqueous extract using in vitro assays. Toxicol in vitro. 2008;22(1):212-8.

14. Prasanna R, Harish CC, Pichai R, Sakthisekaran D, Gunasekaran P. Anticancer effect of Cassia auriculata leaf extract in vitro through cell cycle arrest and induction of apoptosis in human breast and larynx cancer cell lines. Cell Biol Int. 2009;33(2):127-34.

15. Salauddin M, Jalapure SS. Evaluation of anti-diabetic activity of Cassia glauca Lam, leaf in STZ induced diabetic rats. Iranian J of Pharmacology and Therapeutics. 2010;9:29-33.

16. Farswan M, Mazumder PM, Percha V. Protective effect of Cassia glauca Linn. On the serum glucose and hepatic enzymes level in STZ induced NIDDM in rats. Indian J Pharmacol. 2009;41(1):19-22.
17. Kumar D, Arora S, Verma A. Fatty acid composition and Antimicrobial and Antioxidant activity of Cassia glauca seed extracts. International Journal of Phytopharmacology. 2013;4(2):113-8.

18. El-Sayed MM, Abdel-Aziz MM, Abdel-Gawad MM, El-Sayed S, AbdelHameed WSA, Ezzat E, et al. Chemical Constituents and Cytotoxic activity of Cassia glauca Lan. Leaves. Life Science Journal. 2013;10(3):1617-25.

19. Birajdar ZJ, Kulkarni PV, Patel VR, Delvadia P, Manure MJY. Effect of Cassia glauca LAMK, Leaves Extract on Cardiovascular and Renal Complications Associated with Streptozotocin-Induced Diabetic Rats. International Journal of Pharma Sciences and Research. 2015;6(2):322-33.

20. Mukherjee PK. Quality control of herbal drug. New Dehli: Business horizon. 2002.

21. Peach K, Treasy MV. Modern method of plant analysis. New Dehli: Narosa Publication house. 1995.

22. Kokate CK. Practical Pharmacognosy. IIn edition. Pune: Nirali Publication. 1994.

23. OECD. Guidance document on acute oral toxicity 423. Environmental Health and Safety Monograph Series on Testing Assessment. 2009;22-5.

24. Masiello P, Broca C, Gross R, Roye M, Manteghetti M, Hillaire-Buys D, et al. Experimental NIDDM: Development of a new model in adult rats administered streptozotocin and nicotinamide. Diabetes. 1998;47(2):224-9.

25. Alenzi FQ. Effect of Nicotinamide on Experimental Induced Diabetes. Iran J Allergy Asthma Immunol. 2009;8(1):11-8.

26. Szkudelski T. The mechanism of alloxan and streptozotocin action in $\beta$-cells of the rat pancreas. Physiol Res. 2001;50(6):537-46.

27. Lenzen $\mathrm{S}$. The mechanisms of alloxan and streptozotocin induced diabetes. Diabetologia. 2008;51(2):216-26.

28. Rao BK, Sudarshan PR, Rajasekhar MD, Nagaraju N, Rao CA. Antidiabetic activity of Terminalia pallida fruit in alloxan induced diabetic rat. J Ethnopharmacol. 2003;85(1):169-72.

29. Prince PSM, Kamalakkannan N. Rutin improves glucose homeostasis in streptozotocin diabetic tissues by altering glycolytic and gluconeogenic enzymes. J Biochem Mol Toxicol. 2006;20(2):96-102.

30. Ding $\mathrm{Y}$, Shi $\mathrm{X}$, Shuai $\mathrm{X}, \mathrm{Xu} \mathrm{Y}$, Liu $\mathrm{Y}$, Liang $\mathrm{X}$. Luteolin prevents uric acid induced pancreatic $\beta$-cell dysfunction. J Biomed Res. 2014;28(4):292-8.

31. Coskun O, Kanter M, Korkmaz A, Oter S. Quercetin, a flavonoid antioxidant, prevents and protects streptozotocin-induced oxidative stress and beta-cell damage in rat pancreas. Pharmacol Res. 2005;51(2):117-23.

32. Stewart LK, Wang Z, Ribnicky D, Soileau JL, Cefalu WT, Gettys TW. Failure of dietary quercetin to alter the temporal progression of insulin resistance among tissues of C57BL/6 J mice during the development of diet-induced obesity. Diabetologia. 2009;52(3):514-23.

33. Pulok KM, Kuntal M, Kakali M, Peter $\mathrm{JH}$. Leads from Indian medicinal plants with hypoglycaemic potentials. J Ethnopharmacol. 2006;106(1):1-28.

34. Hideaki K, Taka-aki M, Yoshihisa N, Dan K, Munehide M, Yoshimitsu Y. Oxidative stress and JNK pathway in diabetes. Curr Diab Rev. 2005;1(1):6572. 
PICTORIAL ABSTRACT

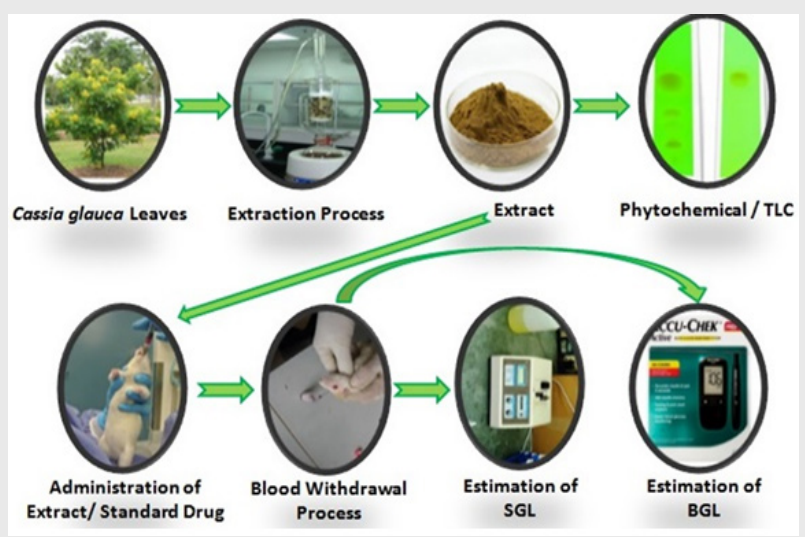

\section{SUMMARY}

The objective of the present study was to screen the anti-hyperglycaemic and anti-hyperlipidemic activities of leaf extracts of the Cassia glauca plant. First of all phytochemical studies of all extracts were carried out in detail followed by their screening studies on rats was performed. The parameters viz; OGTT, FSGL, change in body weight, and other biochemical parameters were estimated. The findings of phytochemical and biological studies revealed that most therapeutic active phytoconstituents were present in the methanolic leaf extract of $C$. glauca in comparison to other extracts. Based on results obtained, it was postulated that leaves of $C$. glauca contain various bioactive phytoconstituents and out of them, flavonoids were more prominent entities for observed biological activities. Further, the results of the study also revealed that the methanolic extract of $C$. glauca possesses the potential antidiabetic and anti-hyperlipidemic property.

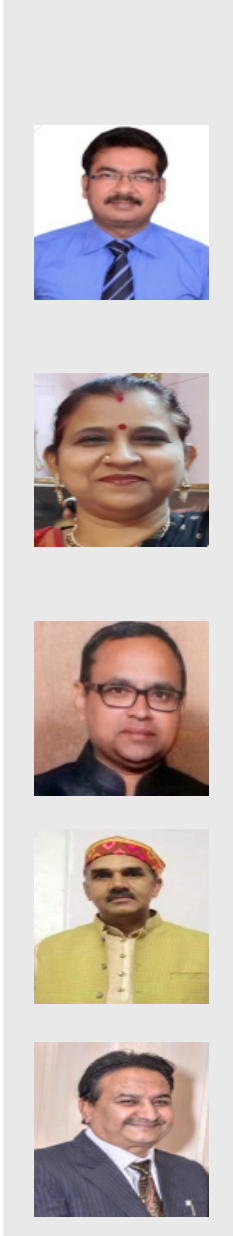

\section{About Authors}

Vinay Kumar Gupta is presently working as Lecturer in the Department of Pharmacology at Uttar Pradesh University of Medical Sciences, Saifai, Etawah, Uttar Pradesh, India. He is also pursuing Ph.D. from Uttarakhand Technical University, Dehradun. He is having more than 12 years of academic and research experience. He has published 12 research articles in various National and International scientific journals of repute. His core area of research is Phytochemical and Pharmacological evaluation.

Prof. (Dr.) Asha Pathak is working as Professor in the Department of Pharmacology at Uttar Pradesh University of Medical Sciences, Saifai, Etawah, Uttar Pradesh, India. She is having more than 14 years of teaching and research experience. She has published 20 Research articles in National and International Journals. She is coordinating ADR monitoring centre and received award of best coordinator for ADR monitoring centre of Uttar Pradesh. She is guiding 3 MD students and $1 \mathrm{Ph} . \mathrm{D}$. scholar.

Prof. (Dr.) Chandra Veer Singh is working as Professor in the Department of Pharmacology at Uttar Pradesh University of Medical Sciences, Saifai, Etawah, Uttar Pradesh, India. He is having 14 years of teaching experience. He has published 07 Research articles in National and International Journals. He is guiding 3 MD students. His core area of interest is Basic Principles of Pharmacology and Therapeutics.

Prof. (Dr.) Manoj Gahlot is working as Professor in Department of Pharmaceutical Sciences at Shri Guru Ram Rai University, Dehradun, Uttarakhand, India. He is having 20 years of academic and research experience. He has published more than 25 research articles in various National and International scientific journals of repute. He has guided 6 Ph.D. scholars. His core area of research is Phytochemical, medicinal chemistry and spectroscopy.

Prof. (Dr.) Devender Pathak is presently working as Dean, Faculty of Pharmacy at Uttar Pradesh University of Medical Sciences, Saifai, Etawah, Uttar Pradesh, India. He has published more than 150 publications in National and International Journals. He was also Dean at faculty of Pharmacy, Uttar Pradesh Technical University, Lucknow. He is having 30 years of academic and research experience. He has guided 5 Ph.D. and more than 100 Post Graduates.

Cite this article: Gupta VK, Pathak A, Singh CV, Gahlot M, Pathak D. Screening of Anti-Hyperglycaemic and Antihyperlipidemic Activities of Leaves Extracts of Cassia glauca Lam. on Streptozotocin-nicotinamide Induced NIDDM Rats. Indian J of Pharmaceutical Education and Research. 2021;55(4):1115-24. 